\title{
Elevated Milk Soluble CD14 in Bovine Mammary Glands Challenged with Escherichia coli Lipopolysaccharide
}

\author{
J.-W. Lee, ${ }^{\star}$ M. J. Paape,† T. H. Elsasser, $¥$ and X. Zhao* \\ ${ }^{*}$ Department of Animal Science, McGill University, Ste-Anne-de-Bellevue, Quebec, H9X 3V9, Canada; and †Immunology and Disease \\ Resistance Laboratory and ¥Growth Biology Laboratory, USDA-ARS, Beltsville, MD 20705
}

\begin{abstract}
The purpose of this study was to determine whether soluble CD14 (sCD14) in milk was affected by stage of lactation, milk somatic cell count (SCC), presence of bacteria, or lipopolysaccharide (LPS)-induced inflammation. Milk samples from 100 lactating cows (396 functional quarters) were assayed for sCD14 in milk to determine effects of stage of lactation, SCC, and intramammary infection. The concentration of sCD14 was highest in transitional milk ( 0 to $4 \mathrm{~d}$ postpartum) and in milk with high SCC (>750,000 cells $/ \mathrm{ml})$. Most of the infected quarters (> 80\%) were infected by coagulasenegative staphylococci and yeast. No difference was found between noninfected and infected quarters. One quarter of six healthy lactating cows was challenged with $100 \mu \mathrm{g}$ LPS in order to study the kinetics of sCD14 during an LPS-induced inflammation. Milk samples were collected at various intervals until $72 \mathrm{~h}$ after injection. Rectal temperature, milk tumor necrosis factor$\alpha$, and interleukin- 8 increased immediately after challenge. The increase in sCD14 paralleled the increase in SCC, peaked at $12 \mathrm{~h}$, and started to decline after $24 \mathrm{~h}$. Serum leakage, as characterized by the level of bovine serum albumin in milk, peaked at $4 \mathrm{~h}$ and then gradually decreased. All parameters remained at basal levels in control quarters throughout the study. In vitro experiments indicated that neutrophils released sCD14 in response to LPS in a dose-dependent manner. The results indicate that the concentration of sCD14 was significantly increased in milk after LPS challenge. The increase was not likely due to serum leakage. Instead, infiltrated neutrophils might be the main source of increased sCD14 in milk during inflammation.
\end{abstract}

(Key words: CD14, LPS, Escherichia coli, mastitis)

Abbreviation key: BAL = bronchoalveolar lavage, BSA = bovine serum albumin, $\mathbf{C S F}=$ cerebrospinal fluid, IL = interleukin, LBP = lipopolysaccharide-bind-

Received December 17, 2002.

Accepted February 4, 2003.

Corresponding author: X. Zhao; e-mail: Zhao@macdonald. mcgill.ca. ing protein, $\mathbf{L P S}=$ lipopolysaccharide, $\mathbf{T N F}=$ tumor necrosis factor.

\section{INTRODUCTION}

Recognition of lipopolysaccharide (LPS) by the innate immune system is critical to elicit inflammatory responses. The cellular receptor for interacting with LPS is CD14, a 53 to $55 \mathrm{kDa}$ glycosylphosphotidylinositol-anchored protein expressed on the membrane of monocytes/macrophages and neutrophils (Haziot et al., 1988; Wright et al., 1991; Paape et al., 1996). Although expression of CD14 on neutrophils is low (Ball et al., 1982), expression can be upregulated by stimulation with cytokines (Buckle et al., 1990). A soluble form of CD14 (sCD14) was found in normal human serum, urine, and milk (Bazil et al., 1986; Labéta et al., 2000; Filipp et al., 2001). Shedding of mCD14 from monocytes and neutrophils results in sCD14 in body fluids (Bazil and Strominger, 1991; Haziot et al., 1993). The direct binding of LPS to CD14 is minimal and the presence of LPS-binding protein (LBP), an acute phase protein in serum, accelerates binding (Hailman et al., 1994). In response to LPS/LBP complexes, monocytes/macrophages release a spectrum of cytokines, including tumor necrosis factor (TNF)- $\alpha$, interleukin (IL)-1, IL-6, and IL-8, to initiate host defense (Martin, 2000). However, overwhelming production of TNF- $\alpha$ is the main causation of multiple organ failure and death as seen during "septic shock" (Waage et al., 1989).

Elevated serum concentration of sCD14 has been reported in patients with various diseases, including lupus erythematosus (Nockher et al., 1994), malaria (Wenisch et al., 1996), and tuberculosis (Juffermans et al., 1998). Increased sCD14 was also detected in the bronchoalveolar lavage (BAL) fluid from patients with acute respiratory distress syndrome (Martin et al., 1997) and in cerebrospinal fluid (CSF) of patients with bacterial meningitis (Cauwels et al., 1999). The biological function of sCD14 has been extensively investigated. Soluble CD14 was shown to modulate humoral and cellular immune responses by interacting with both $\mathrm{B}$ and T lymphocytes (Arias et al., 2000; Filipp et al., 2001). Recombinant human sCD14 was able to prevent LPS- 
induced septic shock and TNF- $\alpha$ production in mice (Haziot et al., 1994; Haziot et al., 1995; Stelter et al., 1998). Moreover, LBP has been shown to interact with sCD14 to rapidly acquire LPS and transport it to highdensity lipoprotein (Wurfel et al., 1995). This process leads to detoxification of LPS in plasma. Administration of recombinant bovine sCD14 (rbosCD14) decreased mortality of mice intraperitoneally challenged with LPS, and reduced severity of mastitis in mice after intramammary challenge with Escherichia coli (E. coli) (Lee et al., in press).

Soluble CD14 plays a crucial role in protecting the host from LPS challenge, or infection caused by Gramnegative bacteria. Mastitis caused by $E$. coli is a common management-related problem in dairy cattle, and causes a great deal of economic loss in the dairy industry. However, pathogenesis of $E$. coli and the response of the host immune system to this pathogen in the mammary gland are not well understood. There is general agreement that LPS, a cell wall component of Gram-negative bacteria, is the main pathogenic factor involved in infections by $E$. coli (Rietschel et al., 1994). Use of LPS to simulate $E$. coli intramammary infection is commonly used (Paape et al., 1974; Shuster et al., 1993). The mammary gland is a unique organ in terms of its biological function and structure. The existence of sCD14 in milk may protect dairy calves from gastrointestinal infections, and cows from mastitis. In the present study, we identified factors affecting concentration of sCD14 in milk, as well as the change in sCD14 in milk after intramammary challenge with LPS.

\section{MATERIALS AND METHODS}

\section{Animals and Milk Sample Collection}

Fore-milk samples were collected aseptically from 100 lactating Holstein cows at the Beltsville Agriculture Research Center before morning milking for determination of SCC, infection status and concentration of sCD14. Milk samples were categorized according to infection status (infected or noninfected), stage of lactation (transitional $=0$ to $4 \mathrm{~d}$, early $=5$ to $100 \mathrm{~d}$, mid $=$ 101 to $200 \mathrm{~d}$, or late $=>200 \mathrm{~d}$ ), and level of SCC (low $=<250,000$ cells $/ \mathrm{ml}$, medium $=250,000$ to 750,000 cell $\mathrm{s} /$ $\mathrm{ml}$, or high $=>750,000$ cell $\mathrm{s} / \mathrm{ml})$. For endotoxin challenge, six clinically normal Holstein cows, in mid-lactation, were selected. Foremilk was collected aseptically 72 and $24 \mathrm{~h}$ before scheduled challenges. Selection criteria included noninfected mammary quarters and SCC less than 250,000 cells $/ \mathrm{ml}$ milk. Use of animals for the LPS challenge study was approved by the Beltsville Agricultural Research Center's Animal Care and Use Committee.

\section{Intramammary Challenge with LPS}

One of the four mammary quarters was injected with $100 \mu \mathrm{g}$ LPS (E. coli O111:B4) (Sigma, St. Louis, MO) in $10 \mathrm{ml}$ sterile $0.85 \%$ normal saline immediately after the morning milking. One control quarter was injected with $10 \mathrm{ml}$ of sterile saline. Rectal temperatures and foremilk samples were taken $0,1,2,4,6,8,10,12,24$, 48 , and $72 \mathrm{~h}$ relative to injection.

\section{Bacterial Culture}

Immediately after sample collection, each sample was plated in a $0.05-\mathrm{ml}$ volume onto Trypticase soy blood agar. Diagnostic bacteriology was performed according to established guidelines (Harmon et al., 1990).

\section{Sample Preparation}

An aliquot $(2 \mathrm{ml})$ of the milk sample was removed for SCC. The remaining sample was decanted into 40 $\mathrm{ml}$ round-bottom centrifuge tubes and centrifuged at $46,000 \times \mathrm{g}$ for $30 \mathrm{~min}$ at $4^{\circ} \mathrm{C}$. After centrifugation, the fat layer was removed and the skimmed milk was carefully decanted into new centrifuge tubes followed by centrifugation at $46,000 \times \mathrm{g}$ for $30 \mathrm{~min}$ at $4^{\circ} \mathrm{C}$. The clear whey was removed and stored in aliquots at $-20^{\circ} \mathrm{C}$.

\section{Determination of SCC}

Samples were heated for $15 \mathrm{~min}$ at $60^{\circ} \mathrm{C}$ and maintained at $40^{\circ} \mathrm{C}$ until being counted (Fossomatic 90; Foss Electric, Hellerod, Denmark). The cell counter was calibrated every 4 mo with bovine milk somatic cell standards (Dairy Quality Control Institiute Services, Mountain View, MN). Duplicate counts were made on each milk sample.

\section{Competitive Enzyme-linked Immunosorbent Assay (ELISA) for Soluble CD14}

Recombinant bovine sCD14 (rbosCD14) was generated by transfected insect sf/9 cells as described (Wang et al., 2002). Flat-bottom 96-well plates (Immulon 2, Dynatech, Chantilly, VA) were coated with $100 \mu \mathrm{l}$ of rbosCD14 $(5 \mu \mathrm{g} / \mathrm{ml})$ in carbonate/bicarbonate buffer $(\mathrm{pH}$ 9.6) at $4^{\circ} \mathrm{C}$, overnight. The plates were blocked with $2 \%$ gelatin (Sigma) in PBS containing $0.05 \%$ Tween 20 (PBS-T), $200 \mu \mathrm{l}$ per well, at $37^{\circ} \mathrm{C}$ for $1 \mathrm{~h}$. After 3 washes with PBS-T, standards (rbosCD14 serially diluted with PBS-T containing $0.2 \%$ gelatin (PBS-TG)) or samples diluted 50 fold with PBS-TG were mixed with equal volumes of mouse anti-ovine CD14 (Serotec, Raleigh, NC) in PBS-TG (1:500) and added to each well (100 $\mu l)$ in triplicate. The antibody cross-reacts with bovine 
CD14 (Wang et al., 2002). Plates were placed on a shaker at room temperature for $1 \mathrm{~h}$ followed by 3 washes. Then $100 \mu \mathrm{l}$ of horseradish peroxidase-conjugated goat anti-mouse Ig secondary antibody (Promega, Madison, WI) at 1:10,000 dilution in PBS-TG was added to each well and the plates were placed on a shaker at room temperature for $1 \mathrm{~h}$. After 3 washes, peroxidase activity was assayed by adding $100 \mu \mathrm{l}$ of ABTS substrate solution (Kirkgaard \& Perry Laboratories, Gaithersburg, MD) and allowed for color development in the dark for $15 \mathrm{~min}$. The absorbance was determined by a microplate reader at $405 \mathrm{~nm}$ and the concentration of sCD14 was calculated by referring to a standard curve.

\section{ELISA for Bovine Serum Albumin}

Flat-bottom 96 -well plates were coated with $1 \mu \mathrm{g} / \mathrm{ml}$ rabbit anti-bovine serum albumin (BSA) mAb (Bethyl, Montgomery, TX) in carbonate/bicarbonate buffer $(\mathrm{pH}$ 9.6) at $4^{\circ} \mathrm{C}$, overnight. The plates were blocked with $2 \%$ gelatin in PBS-T, $200 \mu \mathrm{l}$ per well, at $37^{\circ} \mathrm{C}$ for $1 \mathrm{~h}$. After 3 washes, standards and diluted samples were added in triplicates $(100 \mu \mathrm{l} / \mathrm{well})$, and incubated at room temperature for $1 \mathrm{~h}$. The plates were washed 3 times and $100 \mu \mathrm{l} \mathrm{HRP-conjugated} \mathrm{sheep} \mathrm{anti-BSA} \mathrm{mAb} \mathrm{(Bethyl)}$ at 1:5000 in PBS-TG was added per well. At the end of $1 \mathrm{~h}$ incubation at room temperature, plates were washed 3 times and $100 \mu \mathrm{l} /$ well of ABTS substrate solution was added. After $15 \mathrm{~min}$, absorbance was determined with a microplate reader at $405 \mathrm{~nm}$ and the concentration of BSA was calculated by referring to a standard curve.

\section{Cytokine Detection}

The concentration of TNF- $\alpha$ in milk was measured by specific double antibody radioimmunoassay (RIA) as described (Kenison et al., 1990). Milk IL-8 was determined using a commercially available human IL-8 enzyme-linked immunosorbent assay kit (R\&D Systems, Minneapolis, MN), which has been shown to cross-react with bovine IL-8 (Shuster et al., 1997).

\section{Neutrophil Isolation}

Bovine neutrophils were isolated from whole blood taken from healthy Holstein cows as described (Carlson and Kaneko, 1973) with slight modifications. Heparinanticoagulated blood was mixed with an equal volume of $\mathrm{Ca}^{2+}$-free Hank's balanced salt solution (HBSS, GIBCO/BRL, Gaithersburg, MD) and added onto $20 \mathrm{ml}$ Ficoll-Paque solution $(1.077 \mathrm{~g} / \mathrm{ml}$, Amersham Biosciences, Piscataway, NJ) in $50 \mathrm{ml}$ tubes. After centrifugation at $1500 \times \mathrm{g}$ for $40 \mathrm{~min}$ at $4^{\circ} \mathrm{C}$, the plasma, buffy coat and upper portion of the red blood cell layer were aspirated and discarded. Neutrophils were isolated by hypotonic lysis of remaining red blood cells with Tris$\mathrm{NH}_{4} \mathrm{Cl}\left(0.017 \mathrm{M}\right.$ Tris base; $\left.0.144 \mathrm{M} \mathrm{NH}_{4} \mathrm{Cl}\right)$. Ice-cold HBSS was added to restore isotonicity. Cell suspension was centrifuged at $1000 \times \mathrm{g}$ for $10 \mathrm{~min}$ at $4^{\circ} \mathrm{C}$ and resuspended in HBSS $\left(10^{7}\right.$ cells $\left./ \mathrm{ml}\right)$. This procedure usually produced a cell fraction containing $>95 \%$ neutrophils determined by differential cell counting of 100 cells. Viability was $>99 \%$ as determined by trypan blue exclusion.

\section{In vitro Stimulation of Neutrophils}

LPS was suspended in sterile HBSS made with nonpyrogenic water and serially diluted to desired concentrations. Isolated neutrophils, $3 \times 10^{6}$ cells, were incubated with $500 \mu \mathrm{l}$ of various dilutions of LPS at $37^{\circ} \mathrm{C}$ with slight agitation. After incubation for $3 \mathrm{~h}$, cells were spun down at $500 \times \mathrm{g}$ for $10 \mathrm{~min}$. The supernatant was collected and stored at $-20^{\circ} \mathrm{C}$ until assayed for sCD14.

\section{Statistical Analysis}

The data were analyzed by least squares means using the general linear models procedure of SAS (SAS Inst. Inc., Cary, NC) according to the model

$$
\mathrm{Y}_{\mathrm{ijk}}=\mu+\mathrm{Q}_{\mathrm{i}}+\mathrm{D}_{\mathrm{j}}+\mathrm{S}_{\mathrm{k}}+\mathrm{I}_{\mathrm{l}}+\mathrm{D} \times \mathrm{S}_{\mathrm{jk}}+\mathrm{e}_{\mathrm{ijkl}}
$$

where

$$
\begin{aligned}
\mathrm{Y}_{\mathrm{ijkl}}= & \text { dependent variable "concentration of } \\
& \text { sCD14", } \\
\mu= & \text { mean, } \\
\mathrm{Q}_{\mathrm{i}}= & \text { effect of quarter (left front, left rear, right } \\
& \text { front, right rear), } \\
\mathrm{D}_{\mathrm{j}}= & \text { effect of stage of lactation (transitional, } \\
& \text { early, mid, late), } \\
\mathrm{S}_{\mathrm{k}}= & \text { effect of SCC (low, medium, high), } \\
\mathrm{I}_{\mathrm{l}}= & \text { effect of infection status (infected, nonin- } \\
& \text { fected), } \\
\mathrm{D} \times \mathrm{S}_{\mathrm{jk}}= & \text { effect of interaction of stage of lactation by } \\
& \text { SCC, } \\
\mathrm{e}_{\mathrm{ijkl}}= & \text { residual effect. }
\end{aligned}
$$

The interaction of SCC by infection status was initially included in the model, and was removed due to lack of significance. For the other parameters, data are presented as mean \pm SEM and compared to the mean observed prior to intramammary challenge using the MIXED procedure of SAS. 
Table 1. Effect of intramammary infection, SCC and stage of lactation on concentration of soluble CD14 in milk.

\begin{tabular}{lr}
\hline Categories & $\mathrm{sCD} 14(\mu \mathrm{g} / \mathrm{ml})$ \\
\hline Status of intramammary infection & \\
Noninfected $(\mathrm{n}=320)$ & $6.90 \pm 0.17^{\mathrm{a}}$ \\
Infected $(\mathrm{n}=76)$ & $6.62 \pm 0.25^{\mathrm{a}}$ \\
Level of SCC & \\
Low, $<250,000$ cells $/ \mathrm{ml}$ & $6.13 \pm 0.28^{\mathrm{a}}$ \\
Medium, 250,000-750,000 cells $/ \mathrm{ml}$ & $6.50 \pm 0.30^{\mathrm{a}}$ \\
High, > 750,000 cells $/ \mathrm{ml}$ & $7.65 \pm 0.29^{\mathrm{b}}$ \\
Stage of lactation & \\
Transitional, 0-4 d & $11.39 \pm 0.49^{\mathrm{a}}$ \\
Early, 5-100 d & $5.46 \pm 0.27^{\mathrm{b}}$ \\
Mid, 101-200 d & $4.56 \pm 0.27^{\mathrm{c}}$ \\
Late, $>200 \mathrm{~d}$ & $5.63 \pm 0.20^{\mathrm{b}}$ \\
\hline
\end{tabular}

${ }^{\mathrm{a}, \mathrm{b}, \mathrm{c}}$ Means in the same category with different superscript statistically differ $(P<0.05)$.

\section{RESULTS}

\section{Measurement of sCD14 in Milk}

Based on milk samples collected from 100 lactating cows (396 functional quarters), the effect of status of infection, SCC, and stage of lactation on the concentration of sCD14 in milk are shown (Table 1). The majority of the infections were caused by coagulase-negative staphylococci ( $78 \%, \mathrm{n}=59$ quarters). Remaining infections consisted of yeast ( $\mathrm{n}=5$ quarters), Staphylococcus aureus ( $\mathrm{n}=5$ quarters) and coliforms ( $\mathrm{n}=4$ quarters). There was no difference $(P>0.05)$ in the concentration of sCD14 between infected and noninfected quarters or among infections caused by different pathogens. The concentration of sCD14 was highest $(P<0.05)$ in milk with SCC $>750,000$ cells $/ \mathrm{ml}(7.65 \pm 0.29 \mu \mathrm{g} / \mathrm{ml})$, when compared to the medium $(6.50 \pm 0.30 \mu \mathrm{g} / \mathrm{ml})$ and low $(6.13 \pm 0.28 \mu \mathrm{g} / \mathrm{ml})$ SCC categories. Transitional milk, 0-4 d postpartum, had the highest concentration of $\operatorname{sCD} 14(11.39 \pm 0.49 \mu \mathrm{g} / \mathrm{ml})$ in comparison with other stages of lactation $(P<0.05)$. Furthermore, the concentration of sCD14 was lower $(P<0.05)$ in milk from midlactation cows $(4.56 \pm 0.27 \mu \mathrm{g} / \mathrm{ml})$ when compared to concentrations for early $(5.46 \pm 0.27 \mu \mathrm{g} / \mathrm{ml})$ and late lactation cows $(5.63 \pm 0.20 \mu \mathrm{g} / \mathrm{ml})$.

\section{Intramammary Challenge with LPS}

In order to investigate the kinetics of sCD14 in milk during an LPS-induced inflammation, $100 \mu \mathrm{g}$ LPS was injected into left front quarters of 6 mid-lactation cows. Rectal temperature increased in all challenged cows and peaked $\left(41.3 \pm 0.3^{\circ} \mathrm{C}\right)$ at $6 \mathrm{~h}$ postinjection. (Figure 1A). The response of TNF- $\alpha$ increased $2 \mathrm{~h}$ postinjection $(P<0.05)$. Maximal TNF- $\alpha$ activity $(27.51 \pm 6.31 \mathrm{ng} /$ $\mathrm{ml})$ occurred $8 \mathrm{~h}$ postinjection $(P<0.01)$. The concentration of IL-8 increased between 2 to $6 \mathrm{~h}$ (Figure 1C).

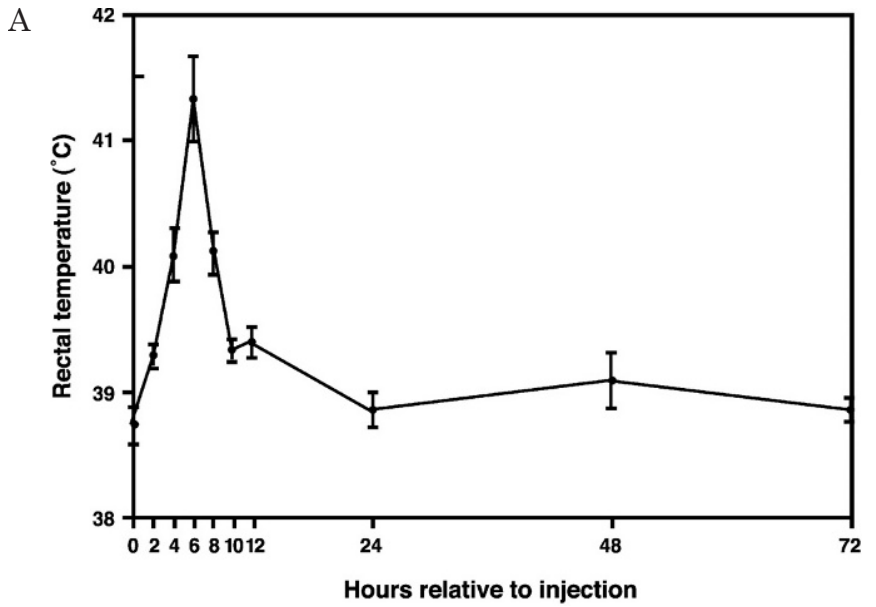

B
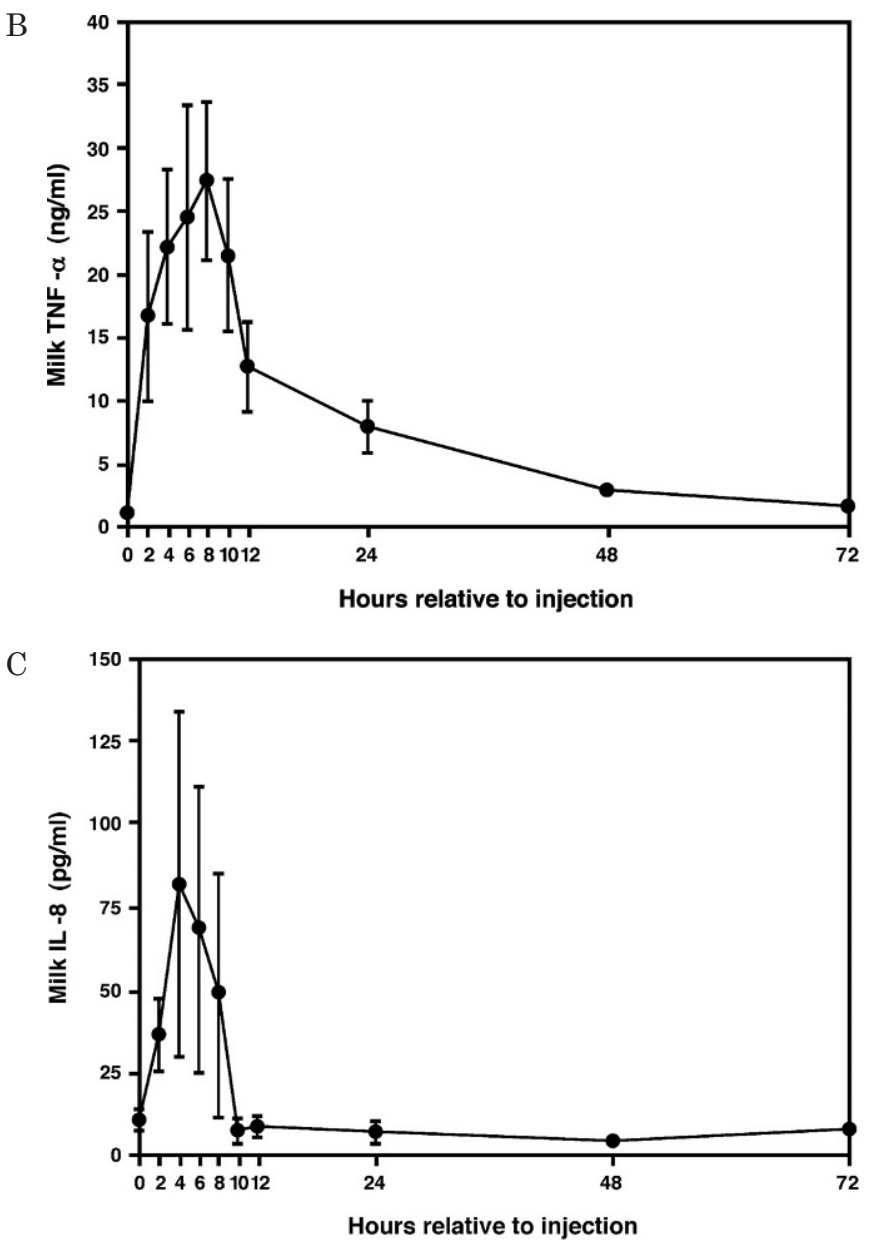

Figure 1. Rectal temperature (A), and concentration of TNF- $\alpha$ (B) and IL-8 (C) in milk during a LPS-induced intramammary inflammation. Left front quarters of six healthy cows were challenged with $100 \mu \mathrm{g}$ LPS after milking (time $=0 \mathrm{~h}$ ). Data are presented as the mean \pm S.E.M. 
Increases in TNF- $\alpha$ and IL-8 were not observed in control quarters injected with saline (data not shown).

Milk SCC increased dramatically in challenged quarters (Figure 2A). The cell count rapidly increased at 4 $\mathrm{h}(P<0.05)$ after injection and reached its peak between 8 to $24 \mathrm{~h}$ after injection. On the other hand, milk SCC remained stable in control quarters. To ensure that no new intramammary infections occurred during the study, milk samples were plated on blood agar plates every $24 \mathrm{~h}$, and all quarters remained free of infection throughout the study.

The concentration of BSA in milk was measured as an indicator of the breakdown in the blood/milk barrier. Compared to the basal concentration, milk BSA increased at $2 \mathrm{~h}(P<0.01)$, peaked at $4 \mathrm{~h}(P<0.001)$, and gradually declined starting at $8 \mathrm{~h}$ post-injection (Figure $2 \mathrm{~B})$. Variation in the concentration of BSA in milk among cows was very small before LPS injection ( 0.194 $\pm 0.01 \mathrm{mg} / \mathrm{ml})$. However, the variation became quite large $(4.36 \pm 1.92 \mathrm{mg} / \mathrm{ml})$ at the peak, indicating that the response to LPS was very different among cows.

The basal concentration of sCD14 averaged $4.61 \pm$ $0.59 \mu \mathrm{g} / \mathrm{ml}$. All LPS challenged quarters showed significantly elevated concentrations of sCD14 at $8 \mathrm{~h}$ postinjection $(P<0.05)$ (Figure $2 \mathrm{C})$. Milk sCD14 reached the highest concentration at $12 \mathrm{~h}(21.49 \pm 3.5 \mu \mathrm{g} / \mathrm{ml}, P$ $<0.001$ ) and started to decline at $48 \mathrm{~h}$ after challenge.

\section{In vitro Stimulation of Neutrophils with LPS}

An in vitro assay was carried out to determine if bovine neutrophils release sCD14 extracellularly in response to LPS. The data showed that LPS was able to induce the release of $\mathrm{sCD} 14$ from neutrophils in a dosedependent manner (Figure 3). Lower doses of LPS only slightly increased the release of $\mathrm{sCD} 14$ from neutrophils. However, when 100 and $250 \mu \mathrm{g} / \mathrm{ml}$ of LPS were used, the release of $\mathrm{sCD} 14$ was increased 2.9 and 5.5fold, respectively $(P<0.01)$.

\section{DISCUSSION}

CD14 is involved in a spectrum of biological and immunological responses. It has been well documented that mCD14 expressed on leukocytes is the key molecule in recognizing invading pathogens and eliciting a cascade of inflammatory responses. On the other hand, sCD14 has been shown to prevent death induced by "septic shock", inhibit dissemination of pathogens, stimulate lymphocyte proliferation, and facilitate phagocytosis of bacteria. Recently, it has been proposed that $\mathrm{sCD} 14$ in human milk plays a role in breast-feeding associated benefits, such as reduced gastrointestinal infections in infants (Labéta et al., 2000). Because
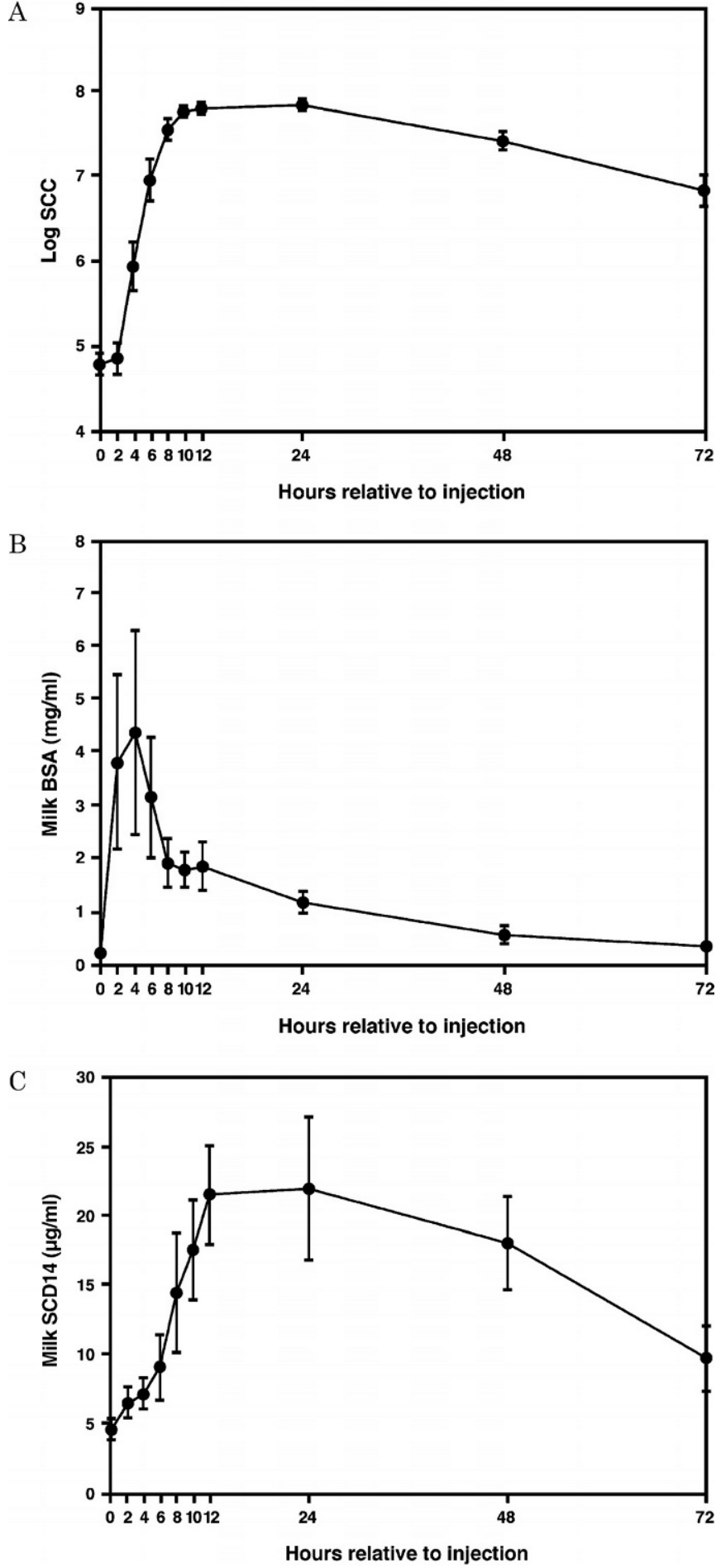

Figure 2. Concentration of somatic cells (A), sCD14 (B), and BSA (C) in milk during an LPS-induced intramammary inflammation. Left front quarters of six healthy cows were challenged with $100 \mu \mathrm{g}$ LPS after milking (time $=0 \mathrm{~h}$ ). Data are presented as the mean \pm S.E.M. 
sCD14 isolated from mouse, human, and bovine, are all biological functional in terms of activating murine B cells (Filipp et al., 2001), consumption of cow milk containing sCD14 could have a similar beneficial effect. We therefore developed an ELISA assay to determine the concentration of sCD14 in normal bovine milk, and study factors that might affect the level of sCD14 in milk.

Based on a herd screening of 100 lactating cows (396 functional quarters), the average concentration of sCD14 in milk, from 320 noninfected quarters, was 6.90 $\pm 0.17 \mu \mathrm{g} / \mathrm{ml}$ (Table 1). This was lower than the concentration of sCD14 in human milk $(14.84 \pm 6.40 \mu \mathrm{g} / \mathrm{ml})$ (Labéta et al., 2000). A higher level of sCD14 in human milk was also reported within the first week postpartum, which is in agreement with our finding. The reason responsible for this observation is unclear. Teleologically, increased sCD14 and immunoglobulins in transitional milk are indispensable in protecting the newborns from infections. Serum sCD14 may be transported into milk as a consequence of increased permeability of epithelium during colostrumgenesis and higher SCC (Miller et al., 1993).

The level of sCD14 was greater $(P<0.05)$ in bovine milk with higher SCC $(>750,000$ cells $/ \mathrm{ml})$. In healthy bovine mammary glands, the predominate cell types are macrophages (35 to 79\%) and neutrophils (3 to 26\%) (Lee et al., 1980; Miller et al., 1993), which have been shown to express CD14 (Paape et al., 1996). Because spontaneous shedding from the membrane of monocytes has been described as the source of sCD14 in culture media (Bazil and Strominger, 1991), these phagocytes might contribute to the increased sCD14 in milk. The percentage of neutrophils increases while the percentage of lymphocytes decreases during early and late lactation (Miller et al., 1993). Therefore, higher levels of sCD14 during early and late lactation might be associated with increased percentage of neutrophils. Surprisingly, infected quarters did not have a higher level of sCD14 $(6.62 \pm 0.25 \mu \mathrm{g} / \mathrm{ml} ; \mathrm{n}=76)$. All infections were subclinical, and more than $80 \%$ of the infections were caused by coagulase-negative staphylococci $(78 \%$; $\mathrm{n}=59)$ and yeast $(6 \% ; \mathrm{n}=5)$ which have been reported to have lower SCC in comparison with other pathogens (Gonzalez-Rodriguez et al., 1995). Therefore, the majority of the infected quarters were not associated with a high SCC causing the concentration of $\mathrm{SCD} 14$ to remain low. Moreover, direct binding of sCD14 to live bacteria has been demonstrated (Jack et al., 1995). However, how the binding affects the measurement of sCD14 in milk needs further investigation. For the infected quarters with increased SCC, it is possible that increased sCD14 from neutrophils may be associated with bacteria and cannot be detected in the whey samples due to

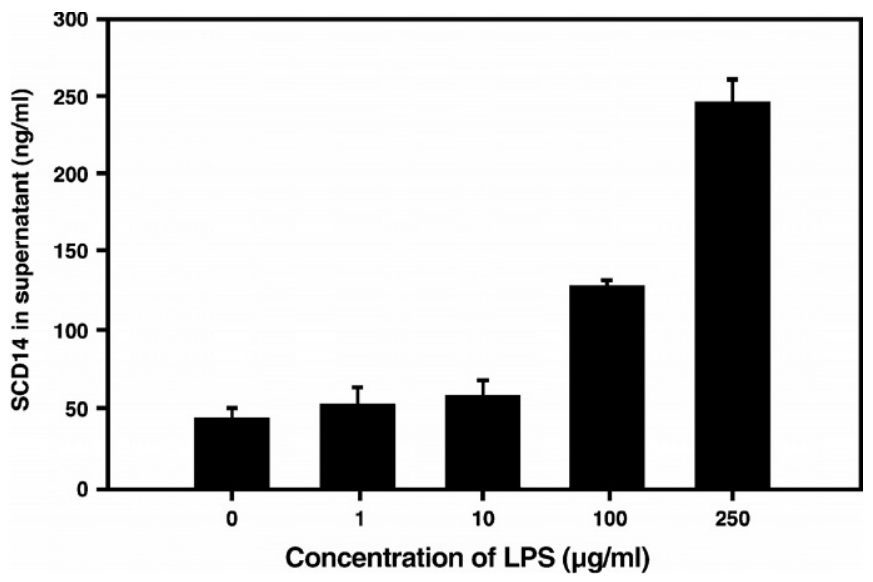

Figure 3. Effect of different concentrations of LPS on release of sCD14 from bovine neutrophils in vitro. Data are presented as the mean \pm S.E.M. from three individual experiments. ${ }^{*} * P<0.01$.

their removal by centrifugation. This could explain why some of the infected quarters even had lower sCD14 in comparison with uninfected quarters of the same cow.

Elevated serum concentration of sCD14 has been reported in patients with various diseases, including lupus erythematosus (Nockher et al., 1994), malaria (Wenisch et al., 1996), and tuberculosis (Juffermans et al., 1998). Markedly increased sCD14 was also detected in the BAL fluid from patients with acute respiratory distress syndrome (Martin et al., 1997) and the CSF from mice with bacterial meningitis (Cauwels et al., 1999). However, this study shows for the first time that the level of sCD14 was elevated in milk during an intramammary inflammation (Figure 2C). Possible sources of sCD14 in milk could be blood serum leakage and cells in the mammary gland. According to our results, the concentration of BSA in milk, an indicator of serum leakage, peaked between 2 to $6 \mathrm{~h}$ after challenge (Figure $2 \mathrm{~B})$. One the other hand, sCD14 in milk did not increase until $8 \mathrm{~h}$ postinjection. These results ruled out the possibility that elevated sCD14 in milk was due to the breakdown of the blood/milk barrier. Human mammary epithelial cells have been shown to produce sCD14 (Labéta et al., 2000). However, we failed to detect cultured bovine mammary epithelial cell-derived sCD14 at both transcriptional and secretory levels (data not shown). On the other hand, the increase in sCD14 after LPS injection paralleled the increase in SCC (Figure 2A), which consists of mostly (95\%) neutrophils (Paape et al., 1979). We therefore tested whether bovine neutrophils released sCD14 in response to LPS in vitro. Although the data show that LPS did induce the release of SCD14 from bovine PMN (Figure 3), the required doses of LPS to elicit a significant response seem much higher than the concentration found during $E$. coli mastitis, as im- 
plicated in a previous study (Dosogne et al., 2002). The lack of LPS-binding protein (LBP) in the in vitro assay may have contributed to the insensitivity of neutrophils to the LPS. LBP has been shown to increase the affinity of mCD14 toward LPS by 1000 fold (Hailman et al., 1994). However, our results confirm that bovine PMN are capable of releasing sCD14 into milk. Previous findings also support neutrophils as the origin of sCD14 in milk. First, both de novo synthesis and membrane expression of CD14 were found to be upregulated in neutrophils isolated from mice with bacterial meningitis (Cauwels et al., 1999). Second, the level of sCD14 was found to be strongly related to the concentration of neutrophils in the BAL from patients with acute lung injury (Martin et al., 1997). Third, expression of mCD14 on bovine neutrophils isolated from blood, normal milk, and milk from LPS-challenged quarters were 3, 68, and $5 \%$, respectively (Paape et al., 1996). This implies that agents in milk or the migration process can up-regulate expression of mCD14 on neutrophils, and that LPS challenge induces the release of CD14. In addition, intracellular CD14 has been reported to be stored in the granules of neutrophils (Detmers et al., 1995; Paape et al., 1996; Rodeberg et al., 1997). Therefore, expression of mCD14 can be augmented in activated neutrophils through degranulation, and this in turns leads to release of sCD14. A direct stimulation of LPS was not able to increase the surface expression of mCD14 in bovine neutrophils (data not shown). However, inflammatory cytokines, such as IL-1 and IL-8, are capable of inducing bovine neutrophil degranulation (Lee et al., unpublished results) and might play a role in the release of sCD14.

In the present study, we demonstrate that sCD14 exists in normal bovine milk, and averages $6.90 \pm 0.1 .7$ $\mu \mathrm{g} / \mathrm{ml}$. The concentration is highest within a few days of parturition and is affected by the SCC. During an intramammary LPS challenge, the increase in sCD14 parallels the increase in SCC, but not the increase in BSA. In vitro stimulation with LPS indicated that neutrophils are capable of releasing sCD14 and might contribute to elevated sCD14 in milk after LPS challenge.

\section{REFERENCES}

Arias, M. A., J. E. Rey Nores, N. Vita, F. Stelter, L. K. Borysiewicz, P. Ferrara, and M. O. Labéta. 2000. Cutting edge: human B cell function is regulated by interaction with soluble CD14: opposite effects on IgG1 and IgE production. J. Immunol. 164:3480-3486.

Ball, E. D., R. F. Graziano, L. Shen, and M. W. Fanger. 1982. Monoclonal antibodies to novel myeloid antigens reveal human granulocyte heterogeneity. Proc. Natl. Acad. Sci. 79:5374-5378.

Bazil, V., V. Horejsi, M. Baudys, H. Kristofova, J. L. Strominger, W. Kostka, and I. Hilgert. 1986. Biochemical characterization of a soluble form of the $53-\mathrm{kDa}$ monocyte surface antigen. Eur. J. Immunol. 16:1583-1589.
Bazil, V., and J. L. Strominger. 1991. Shedding as a mechanism of down-modulation of CD14 on stimulated human monocytes. J. Immunol. 147:567-1574.

Buckle, A. M., Y. Jayaram, and N. Hogg. 1990. Colony-stimulating factors and interferon-gamma differentially affect cell surface molecules shared by monocytes and neutrophils. Clin. Exp. Immunol. 81:339-345.

Carlson, G. P., and J. J. Kaneko. 1973. Isolation of leukocytes from bovine peripheral blood. Proc. Soc. Exp. Biol. Med. 142:853-856.

Cauwels, A., K. Frei, S. Sansano, C. Fearns, R. Ulevitch, W. Zimmerli, and R. Landmann. 1999. The origin and function of soluble CD14 in experimental bacterial meningitis. J. Immunol. 162:47624772.

Detmers, P. A., D. Zhou, D. Powell, H. Lichenstein, M. Kelley, and R. Pironkova. 1995. Endotoxin receptors (CD14) are found with CD16 ( Fc $\gamma$ RIII) in an intracellular compartment of neutrophils that contains alkaline phosphatase. J. Immunol. 155:2085-2095.

Dosogen, H., E. Meyer, A. Sturk, J. van Loon, A. M. Massart-Leën, and C. Burvenich. 2002. Effect of enrofloxacin treatment on plasma endotoxin during bovine Escherichia coli mastitis. Inflamm. Res. $51: 201-205$.

Filipp, D., K. Alizadeh-Khiavi, C. Richardson, A. Palma, N. Paredes, O. Takeuchi, S. Akira, and M. Julius. 2001. Soluble CD14 enriched in colostrums and milk induces B cell growth and differentiation. Proc. Natl. Acad. Sci. 98:603-608.

Gonzalez-Rodriguez, M. C., C. Gonzalo, F. San Primitivo, and P. Carmenes. 1995. Relationship between somatic cell count and intramammary infection of the half udder in dairy ewes. J. Dairy Sci. 78:2753-2759.

Hailman, E., H. S. Lichenstein, M. M. Wurfel, D. S. Miller, D. A. Johnson, M. Kelley, L. A. Busse, M. M. Zukowski, and S. D. Wright. 1994. Lipopolysaccharide (LPS)-binding protein accelerates the binding of LPS to CD14. J. Exp. Med. 179:269-277.

Harmon, R. J., R. J. Eberhart, D. E. Jasper, B. E. Langlois, and R. A. Wilson. 1990. Microbiological Procedures for the Diagnosis of Bovine Udder Infection. 3rd Ed. National Mastitis Council. Arlington, VA.

Haziot, A., S. Chen, E. Ferrero, M. G. Los, R. Silber, and S. M. Goyert. 1988. The monocyte differentiation antigen, CD14, is anchored to the cell membrane by a phosphatidylinositol linkage. J. Immunol. 141:547-552.

Haziot, A., B. Tsuberi, and S. M. Goyert. 1993. Neutrophil CD14: biochemical properties and role in the secretion of tumor necrosis factor- $\alpha$ in response to lipopolysaccharide. J. Immunol. 150:5556-5565.

Haziot, A., G. Rong, V. Bazil, J. Silver, and S. M. Goyert. 1994 Recombinant soluble CD14 inhibits LPS-induced tumor necrosis factor- $\alpha$ production by cells in whole blood. J. Immunol. 152:5868-5876.

Haziot, A, G. Rong, X. Lin, J. Silver, and S. M. Goyert. 1995. Recombinant soluble CD14 prevents mortality in mice treated with endotoxin (lipopolysaccharide). J. Immunol. 154:6529-6532.

Jack, R. S., U. Grunwald, F. Stelter, G. Workalemahu, and C. Schütt. 1995. Both membrane-bound and soluble forms of CD14 bind to Gram-negative bacteria. Eur. J. Immunol. 25:1436-1441.

Juffermans, N. P., A. Verbon, S. J. van Deventer, W. A. Buurman, H. van Deutekom, P. Speelman, and T. van der Poll. 1998. Serum concentrations of lipopolysaccharide activity-modulating proteins during tuberculosis. J. Infect. Dis. 178:1839-1842.

Kenison, D. C., T. H. Elsasser, and R. Fayer. 1990. Radioimmunoassay for bovine tumor necrosis factor: Concentrations and circulating molecular forms in bovine plasma. J. Immunoassay 11:177-187.

Labéta, M. O., K. Vidal, J. E. R. Nores, M. Arias, N. Vita, B. P. Morgan, J. C. Guillemot, D. Loyaux, P. Ferrara, D. Schmid, M. Affolter, L. K. Borysiewicz, A. Donnet-Hughes, and E. J. Schiffrin. 2000. Innate recognition of bacteria in human milk is mediated by a milk-derived highly expressed pattern recognition receptor, soluble CD14. J. Exp. Med. 191:1807-1812.

Lee, C. W., F. B. P. Wooding, and P. Kemp. 1980. Identification, properties, and differential counts of cell populations using elec- 
tron microscopy of dry cows secretion, colostrums, and milk from normal cows. J. Dairy Sci. 47:39-50.

Lee, J.-W., M. J. Paape, and X. Zhao. 2003. Recombinant bovine soluble CD14 reduces severity of experimental Escherichia coli mastitis in mice. Vet. Res. In press.

Martin, T. R., G. D. Rubenfeld, J. T. Ruzinski, R. B. Goodman, K. P. Steinberg, D. J. Leturcq, A. M. Moriarty, G. Raghu, R. P. Baughman, and L. D. Hudson. 1997. Relationship between soluble CD14, lipopolysaccharide binding protein, and the alveolar inflammatory response in patients with acute respiratory distress syndrome. Am. J. Respir. Crit. Care Med. 155:937-944.

Martin, T. R. 2000. Recognition of bacterial endotoxin in the lungs. Am. J. Respir. Cell Mol. Biol. 128:128-132.

Miller, R. H., M. J. Paape, and L. A. Fulton. 1993. The relationship of milk somatic cell count to milk yield for Holstein heifers after first calving. J. Dairy Sci. 76:728-733.

Nockher, W. A., R. Wigand, W. Schoeppe, and J. E. Scherberich. 1994. Elevated levels of soluble CD14 in serum of patients with systemic lupus erythematosus. Clin. Exp. Immunol. 96:15-19.

Paape, M. J., W. D. Schultze, C. Desjardins, and R. H. Miller. 1974. Plasma corticosteroids, circulating leukocyte and milk somatic cell responses to Escherichia coli endotoxin-induced mastitis. Proc. Soc. Exp. Biol. Med. 145:533-539.

Paape, M. J., W. P. Wergin, A. J. Guidry, and R. E. Pearson. 1979. Leukocytes-second line of defense against invading mastitis pathogens. J. Dairy Sci. 62:135-153.

Paape, M. J., E. M. Lilius, P. A. Wiitanen, M. P. Kontio, and R. H. Miller. 1996. Intramammary defense against infections induced by Escherichia coli in cows. Am. J. Vet. Res. 57:477-482.

Rietschel, E. T., T. Kirikae, F. U. Schade, U. Mamat, G. Schmidt, H. Loppnow, A. J. Ulmer, U. Zahringer, U. Seydel, and F. D. Padova. 1994. Bacterial endotoxin: molecular relationships of structure to activity and function. FASEB 8:217-225.
Rodeberg, D. A., R. E. Morris, and G. F. Babcock. 1997. Azurophilic granules of human neutrophils contain CD14. Infect. Immun. 65:4747-4753.

SAS/STAT User's Guide, Version 8, SAS Institute Inc., Cary, NC, 2000.

Shuster, D. E., M. E. Kehrli, and M. G. Stevens. 1993. Cytokine production during endotoxin-induced mastitis in lactating dairy cows. Am. J. Vet. Res. 54:80-85.

Shuster, D. E., M. E. Kehrli, P. Rainard, and M. J. Paape. 1997. Complement fragment C5a and inflammatory cytokines in neutrophil recruitment during intramammary infection with Escherichia coli. Infec. Immun. 65:3286-3292.

Stelter, F., S. Witt, B. Fürll, R. S. Jack, T. Hartung, and C. Schütt. 1998. Different efficacy of soluble CD14 treatment in high- and low-dose LPS models. Eur. J. Clin. Invest. 28:205-213.

Waage, A., P. Brandtaeg, A. Halstensen, P. Kierulf, and T. Espevik. 1989. The complex pattern of cytokines in serum from patients with meningococcal septic shock: association between Interleukin 6, Interleukin 1, and fatal outcome. J. Exp. Med. 169:333-338.

Wang, Y., D. S. Zarlenga, M. J. Paape, and G. E. Dahl. 2002 Recombinant bovine soluble CD14 sensitizes the mammary gland to lipopolysaccharide. Vet. Immunol. Immunopathol. 86:115-124.

Wenisch, C., H. Wenisch, B. Parschalk, S. Vanijanonta, H. Burgmann, M. Exner, K. Zedwitz-Liebenstein, F. Thalhammer, A. Georgopoulos, W. Graninger, and S. Looareesuwan. 1996. Elevated levels of soluble CD14 in serum of patients with acute Plasmodium falciparum malaria. Clin. Exp. Immunol. 105:74-78.

Wright, S. D., R. Ramos, A. Hermanowski-Vosatka, P. Rockwell, and P. A. Detmers. 1991. Activation of the adhesive capacity of CR3 on neutrophils by endotoxin: dependence on lipopolysaccharide binding protein and CD14. J. Exp. Med. 173:1281-1286.

Wurfel, M. M., E. Hailman, and S. D. Wright. 1995. Soluble CD14 acts as a shuttle in the neutralization of lipopolysaccharide (LPS) by LPS-binding protein and reconstituted high density lipoprotein. J. Exp. Med. 181:1743-1754. 